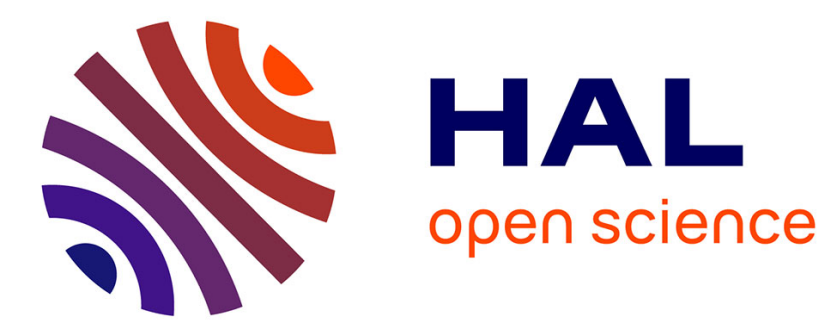

\title{
XAFS Determination of As(V) Associated with Fe(III) Oxyhydroxides in Weathered Mine Tailings and Contaminated Soil from California, U.S.A.
}

\author{
A. Foster, G. Brown, G. Parks, T. Tingle, D. Voigt, S. Brantley
}

\section{- To cite this version:}

A. Foster, G. Brown, G. Parks, T. Tingle, D. Voigt, et al.. XAFS Determination of As(V) Associated with Fe(III) Oxyhydroxides in Weathered Mine Tailings and Contaminated Soil from California, U.S.A.. Journal de Physique IV Proceedings, 1997, 7 (C2), pp.C2-815-C2-816. 10.1051/jp4:1997244 . jpa-00255323

HAL Id: jpa-00255323

https://hal.science/jpa-00255323

Submitted on 1 Jan 1997

HAL is a multi-disciplinary open access archive for the deposit and dissemination of scientific research documents, whether they are published or not. The documents may come from teaching and research institutions in France or abroad, or from public or private research centers.
L'archive ouverte pluridisciplinaire HAL, est destinée au dépôt et à la diffusion de documents scientifiques de niveau recherche, publiés ou non, émanant des établissements d'enseignement et de recherche français ou étrangers, des laboratoires publics ou privés. 


\title{
XAFS Determination of As(V) Associated with Fe(III) Oxyhydroxides in Weathered Mine Tailings and Contaminated Soil from California, U.S.A.
}

\author{
A.L. Foster, G.E. Brown Jr., G.A. Parks, T.N. Tingle*, D.E. Voigt** and S.L. Brantley** \\ Geological \& Environmental Sciences, Stanford University, Stanford CA 94305-2115, U.S.A. \\ * Center for Materials Research, Stanford University, Stanford CA 94305-2115, U.S.A. \\ ** Dept. of Geosciences, The Pennsylvania State University, University Park PA 16802-2714, U.S.A.
}

\begin{abstract}
The speciation of Arsenic (As) in soils and natural waters is critical in determining its environmental fate. As(III) is the most mobile and toxic of the inorganic arsenic species, but is readily oxidized to $A s(V)$, which although still quite toxic is far less mobile. Adsorption to sediment particles may remove As(V) from contaminated water, or the precipitation of arsenic minerals such as scorodite $\left(\mathrm{FeAsO}_{4} \cdot 2 \mathrm{H}_{2} \mathrm{O}\right.$ ) may control the equilibrium aqueous concentration. We have employed XAFS spectroscopy to examine the solid-phase speciation of arsenic in mine tailings samples and a contaminated soil from California. Quantitative speciation of As was determined using XANES fitting methods and EXAFS analysis; in all samples, As(V) predominates. In an oxidized tailings (no residual sulfides), we find As(V) adsorbed/coprecipitated on Fe(III) oxyhydroxides. In less oxidized tailings containing residual sulfides, there is evidence for scorodite or a similar Fe(II) arsenate and a reduced arsenic phase (arsenopyrite or arseniferous pyrite). In a soil contaminated by smelter waste, we detect $\mathrm{Mg}_{3}\left(\mathrm{AsO}_{4}\right)_{2} \cdot 8 \mathrm{H}_{2} \mathrm{O}$ (hoernesite), and suggest the presence of an additional weakly bound $\mathrm{As}(\mathrm{V})$ species. XAFS spectroscopy is one of the few techniques for direct determination of arsenic speciation in complex matrices such as soils and mine tailings.
\end{abstract}

\section{INTRODUCTION}

\begin{abstract}
Arsenic (As) is a common constituent of sulfidic ore deposits: $\mathrm{Cu}$ and $\mathrm{Pb}$ ore can contain 2-5\% As, while Au ore reaches as much as $11 \%$ As [1]. In heavily mined areas such as California's Mother Lode region, unregulated/abandoned mines with tailings piles containing thousands of parts per million arsenic are found near residential areas. A realistic evaluation of the risk posed by these tailings is dependent on accurate determination of arsenic speciation, which can vary over temporal, vertical, and lateral scales. In the oxidized zone of tailings piles, $\mathrm{S}(-\mathrm{II})$ and $\mathrm{Fe}$ (II) oxidation mitigates the release of reduced As species, which in turn are oxidized to As(III) or As(V) (both of which form anionic species in aqueous environments, on mineral surfaces, and in homo-and heterogeneous precipitates). A critical difference in the behavior of these anions lies in their sorption affinity; As(V) binds much more strongly to mineral surfaces than does As(III). The formation of Fe(III) precipitates with high sorptive capacity in surface drainage waters, and as coatings on the surfaces of the tailings grains could retard arsenic mobility significantly. We report results of our ongoing XAFS spectroscopic investigation of arsenic speciation in natural samples, focusing on two mine tailings and a soil contaminated by smelter waste.
\end{abstract}

\section{EXPERIMENTAL}

Ruth Mine ("RM"; Trona, CA) and Argonaut Mine ("AM"; Jackson, CA) tailings samples were collected within the oxidized zone (i.e., above standing water). In order of decreasing abundance, the former contains quartz, illite, calcite, and goethite while the latter contains quartz, illite, pyrite, monazite, and arsenopyrite. SS7 (Palo Alto, CA ) is a contaminated soil containing quartz, albite, amphibole, muscovite, kaolinite/smectite, calcite, and hoemesite $\left(\mathrm{Mg}_{3}(\mathrm{AsO})_{2} \cdot 8 \mathrm{H}_{2} \mathrm{O}\right) . . \mathrm{As}-\mathrm{K}$ edge XAFS spectra were collected at SSRL ( $3 \mathrm{GeV}$ and $90-50 \mathrm{~mA}$ ) under ambient conditions on beamlines VI-2 (Si(111) and IV-3 (Si(220)) from 11,650-12,900eV. Arsenic XANES were collected on beamline IV-3 (resolution $\approx 5$ eV@ As K-edge, 1 mm mono slit width, $0.15 \mathrm{eV}$ step). XAFS data analysis was accomplished using EXAFSPAK [2]; XANES spectra were background subtracted and normalized to the first spline point $(11,885 \mathrm{eV})$. The $\mathrm{k}^{3}$-weighted EXAFS were fit using ab initio phase and amplitude functions calculated using FEFF6.01 [3]). The actual k-range fitted for model compounds was 11-12 $\AA^{-1}$ and 9-10 $\AA^{-1}$ for samples. In sample fits, $\sigma^{2}$ was fixed at $0.005-0.007 \AA^{2}$ for second and higher shells. Final fits were made to the normalized $X(k) * k^{3}$ EXAFS spectrum.

\section{RESULTS AND DISCUSSION}

The energy position of the first inflection point of the edge is indicative of oxidation state; in all samples examined, As(V) is the predominant valence of arsenic present (Fig. 1a). The AM sample has a small shoulder on the low energy side of the spectrum, which is attributed to $\approx 20 \%$ reduced arsenic (as arsenopyrite or arseniferous pyrite). Although the XANES structure 
above the white line is dependent on chemical speciation, and similarities are apparent between crystalline model compounds/adsorption samples and natural samples, we are not in this case able to assign speciation based on XANES analysis alone.

The $k^{3}$-weighted EXAFS of model compounds and samples are presented in Fig. $1 \mathrm{~b}$, and Fourier transforms ( "FT"; $\mathrm{k}$ range $\approx 3-13 \AA^{-1}$, uncorrected for phase shift) of the spectra are shown in Fig. 1c. Fits to adsorption samples and natural samples are overlain on the EXAFS data. RM, AM, and SS7 first shell fits yield 4 to $5( \pm 1)$ oxygens at 1.68-1.72( \pm 0.02$) \AA$, consistent with tetrahedrally coordinated As(V). The full EXAFS fit to the second shell feature in the RM FT yields 1.47 $( \pm 1) \mathrm{Fe}$ at $3.26( \pm 0.02) \AA$, within the range of previously reported values for $A s(V)$ bonded to ferrihydrite/goethite [4]. Agreement between data and fit were improved slightly upon addition of a shell of Al atoms (2.4@3.19( \pm 0.02$) \AA)$, suggesting that a small portion of As(V) may be bound to aluminosilicate clays (see below). EXAFS oscillations of the SS7 spectrum resemble those of $\mathrm{Mg}_{3}\left(\mathrm{AsO}_{4}\right)_{2} .8 \mathrm{H}_{2} \mathrm{O}$ (hoernesite), but the feature in the FT of SS7 at $\approx 2.8 \AA$ is smaller than the corresponding feature in the hornesite FT. Fits of this second shell feature give $1.5( \pm 1) \mathrm{Mg}$ at $3.27( \pm 0.02) \AA$, only half of the Mg atoms in hoernesite [5]. Since no other strong peaks are observed in the FT, a weakly bound (outer-sphere) species of As(V) is postulated, which agrees with chemical data suggesting that As(V) is readily extractable from this soil [6]. Another plausible hypothesis, that of an As(V) species bonding to clay minerals, does not seem likely for SS7 upon comparison of the spectrum of $\mathrm{As}(\mathrm{V})$ adsorbed to gibbsite, a reasonable surrogate for $\mathrm{As}(\mathrm{V})$ adsorbed to $1: 1$ and 2:1 clays. The Al-As distance for the As(V)/gibbsite sorption sample $(3.19( \pm 0.02) \AA)$ is shorter than that in the contaminated soil (3.27 $)$. The AM sample contains at least two arsenic species: the first peak in the FT corresponds to tetrahedrally coordinated As(V), but the second shell corresponds to $3 \mathrm{Fe}$ at $2.41( \pm 0,02) \AA$; this shell is similar, but not identical to the first shell of arsenopyrite $(3 \mathrm{Fe} @$. $2.35 \AA)$. The modal abundance of anseniferous pyrite $(\approx 1 w t \%$ As, measured by electron microprobe) is far greater than arsenopyrite in the AM sample, suggesting that the reduced arsenic contribution may be from pyrite. We have fit the third shell of this sample with $4 \mathrm{Fe}$ atoms at $3.35( \pm 0.02) \AA$, corresponding to the second shell of scorodite. We surmise that a surface coating of scorodite or a similar Fe(III)-As(V) precipitate may have formed on grains, and thus eluded detection by $\mathrm{x}-$ ray diffraction and electron microprobe. In conclusion, we have demonstrated that XAFS spectroscopy has considerable utility in unraveling As speciation in complex mixtures of phases.
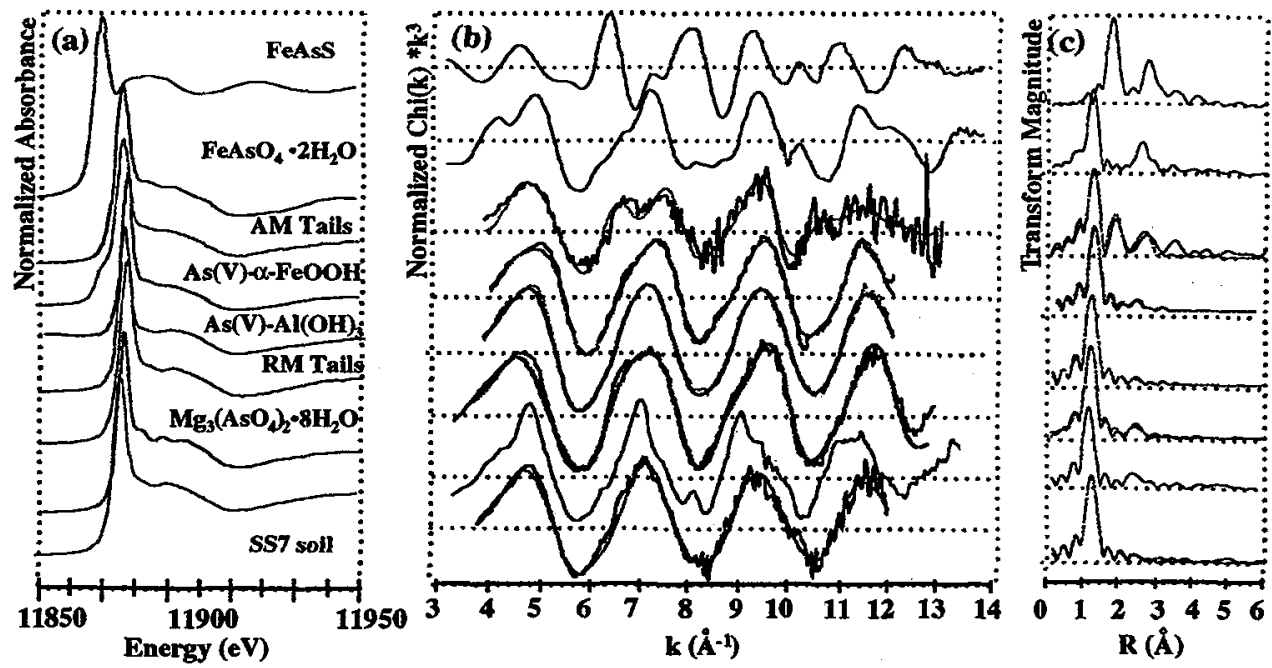

Figure 1: XANES (a), EXAFS (b), and Fourier transforms (c) of arsenic model compounds and samples. Raw data fits in (b) and (c) are shown as dotted lines.

\section{Acknowledgments}

The authors are grateful to the staff of SSRL for their assistance. This work was funded by NSF grant EAR-9406490.

\section{References}

[1]Aczue, J., Nriagu, J., Arsenic in the environment: Part 1 (Wiley-Interscience, New York, 1994) pp.1-17.

[2] Mustre de Leon, J., Rehr, J., Zabinsky, S., and Albers, R. Phys. Rev. Lett. B41 (1991) 8139.

[3] EXAFSPAK, G. George, SSRL (1992).

[4] Waychunas, G., Rea, B., Fuller, C., and Davis, J. Geochim. Cosmochim. Acta 57 (1993) 2251-2269.

[5] The atomic positions in $\mathrm{Mg}_{3}\left(\mathrm{AsO}_{4}\right)_{2} \cdot 8 \mathrm{H}_{2} \mathrm{O}$ have not been determined, so the isostructural, $\mathrm{Mg}$-substituted $\mathrm{Fe}_{3}\left(\mathrm{AsO}_{4}\right)_{2} \cdot 8 \mathrm{H}_{2} \mathrm{O}$ (symplesite) was used in $a b$ inito calculations of the XAFS.

[6] Voigt, D., and Brantley, S., submitted to Appl. Geochem. 